\title{
Phased formation of subjectivity (agency) as phenomenon of development of consciousness
}

\section{Work is executed at financial support RFBR, grant 17-06-00871}

Panov V.I. 1, Kaptsov A.V. ${ }^{2}$, Kolesnikova E.I. ${ }^{3}$

1 Laboratory of ecopsychology of development and psychodidactics, Psychological Institute of Russian Academy of Education, Moscow, Russia, ecovip@mail.ru

2 Department of personnel management, Samara Humanitarian Academy, Samara, Russia, avkaptsov@mail.ru

3 Department of philosophy, Institute of Humanities and Technologies, Samara State Technical University, Samara, Russia, KolesnikovaEl@yandex.ru

Introduction. Problem Statement

The problem of formation of subjectivity becomes particularly relevant in the educational system, as mor attention is paid to the development of personal qualities of graduates, responsibility for their actions, social and professional activity, awareness of life position and, in general, the development of subjective position in relation to themselves and the world around them, manifested in metasubject and universal competencies and educationa
activities

Research Questions

Carrying out of empirical research of the stages of development of subjectivity of University students/ To study the processes occurring at different stages of the formation of subjectivity a pilot study on a sample of engineering students, divided randomly into control (64 people) and experimental (58 people) group was conducted. In the experimental group, classes were conducted by scheme, directed on the development of the stages of the formation of subjectivity in accordance with ecopsychological model. In the control group, training took place in the form of traditional training. For diagnose the stages of formation of subjectivity, the author's method was used

References

Panov V.I. Ecopsychology: Paradigmal search. Psychologica institute of the RAS; Nestor-Istoriya: Moscow; Saint-Petersburg. 2014. p. 304; ISBN 978-5-4469-0415-0

- Panov V.I., Kaptsov A.V., Kolesnikova E. I. Method of evaluation stages of the subjectivity of the participants of educational process. The Effectiveness of individuals, groups and organizations: challenges, achievements and prospects. Kaptsov A.V., Kolesnikova E. I. Development of subject competences of students with different severity stages of the formation of subjectness// Bulletin of the Samara Humanitarian Academy. Series: Psychology. 2018. №2 (22). pp. 110-118. Kantsov A.V Ko Koll

stages of stages of subjectivity of students // Psychology of man as a V. Znakov, A. L. Zhuravlev. - Moscow.: Psychological institute of the RAS. 2018. pp. C 301-308. ISBN 978-5-9270-0381-5 Kaptsov A.V., Kolesnikova E. I. Selectivity of interrelation of reflexivity character and stages of formation of subjectivity Social Sciences and Humanities: Theory and Practice . 2018. 1. pp. 560-576. ISSN 2587-9987

Kaptsov A.V., Kolesnikova E. I. Development of agency of students in the university in terms of competence-based Series: Psychology 2018. 1 (23), pp. 16-33. ISSN 1998-9156. Kaptsov A.V. Kolesnikova E I. Selezneva M. V. Plaksina I. V. Diagnosis stages of development of agency of students. Psychology. Historical-critical Reviews and Curren Researches. 2018, Vol. 7, Is. 5A, pp. 158-169.

Panov, V.I., Kaptsov, A.V., Kolesnikova, E. I. Diagnosis O Stages Of Agency Formation. The European Proceedings of Social \& Behavioural Sciences. 2018. 57. pp. 515-523 https://dx.doi.org/10.15405/epsbs.2018.11.02.57
The content of the diagnosed parameters

\begin{tabular}{|c|c|c|c|}
\hline № & The stage of development & Title & Description \\
\hline 1. & The subject of motivation & $\begin{array}{l}\text { Having a } \\
\text { need }\end{array}$ & $\begin{array}{l}\text { As stressed by V. I. Panov, it is a question of" the natural need of the } \\
\text { individual in the manifestation of mental activity in one form or another " } \\
\text { (Panov, 2014), without which the subsequent stages of subjectivity become } \\
\text { unnecessary. This stage was not included in the content of the method of } \\
\text { diagnosis of the stages of subjectivity' formation. }\end{array}$ \\
\hline 2. & $\begin{array}{l}\text { the subject of perception of } \\
\text { the action-sample }\end{array}$ & Observer & $\begin{array}{l}\text { People at this stage is the method and sequence of steps of the sample } \\
\text { mentally. He must consider and understand the action he must do. But he } \\
\text { does not always understand why he needs to get acquainted with the new } \\
\text { way to solve the task. A person in this position notices that others have not } \\
\text { noticed, but prefers to observe what is happening, and not to take an active } \\
\text { part (passive contemplation). }\end{array}$ \\
\hline 3. & $\begin{array}{l}\text { the subject of imitation, } \\
\text { reproductive reproduction } \\
\text { without voluntary regulation }\end{array}$ & Apprentice & $\begin{array}{l}\text { At this stage, a person prefers to perform work on a model, a template, he } \\
\text { can mechanically repeat for someone a new method of action. Repeating } \\
\text { after someone the way of action off or if he doesn't know the answer, he will } \\
\text { check whether he (accurately had copied), or check how it done by others. } \\
\text { In the position of "Apprentice" although it means the opportunity to use } \\
\text { another method of solution is meant, but with a hint (or on the advice of } \\
\text { authoritative colleagues for teachers). }\end{array}$ \\
\hline
\end{tabular}

4. the subject of arbitrary execution of the sample action under externa control, for the student more often under by the teacher' voluntary

5. the subject of voluntary execution of the sample action under independent, voluntary regulation of the correctness

6. the subject

\begin{tabular}{r|r} 
of \\
ntrol,
\end{tabular} exteriorization of contro subject of expert evaluation of the correctness of the required sample action by other individuals

7. the subject of productive development, when the action - pattern has turned from an object of assimilation into a mean of mastering new, more complex actions or for creative self-expression
Results of the study. Discussion

Results of the Wilcoxon signed-rank test

\begin{tabular}{|c|c|c|c|c|c|}
\hline \multicolumn{2}{|c|}{$\begin{array}{l}\text { The stage of } \\
\text { formation of } \\
\text { subjectivity }\end{array}$} & \multirow{2}{*}{\multicolumn{2}{|c|}{$\begin{array}{l}\text { Valid } \quad \mathrm{T} \\
\text { sperimental group }\end{array}$}} & \multirow[t]{2}{*}{ z } & \multirow[t]{2}{*}{ p-level } \\
\hline & & & & & \\
\hline \multirow{2}{*}{$\begin{array}{l}\text { whole } \\
\text { sample }\end{array}$} & Expert & 58 & 448,00 & 2,70 & 0,01 \\
\hline & Creator & 58 & 451,00 & 1,99 & 0,05 \\
\hline \multirow{3}{*}{$\begin{array}{l}\text { women's } \\
\text { sample }\end{array}$} & Observer & 33 & 141,00 & 1,88 & 0,06 \\
\hline & Expert & 33 & 136,00 & 2,39 & 0,02 \\
\hline & Creator & 33 & 149,00 & 1,72 & 0,09 \\
\hline \multicolumn{6}{|c|}{ control group } \\
\hline \multirow{2}{*}{$\begin{array}{l}\text { Whole } \\
\text { sample }\end{array}$} & Learner & 64 & 550,00 & 2,20 & 0,03 \\
\hline & Creator & 64 & 626,00 & 1,95 & 0,05 \\
\hline \multirow{2}{*}{$\begin{array}{l}\text { Iale } \\
\text { sample }\end{array}$} & Learner & 28 & 75,00 & 1,92 & 0,06 \\
\hline & Creator & 28 & 77,00 & 2,30 & 0,02 \\
\hline & Apprentice & 36 & 141,50 & 2,09 & 0,04 \\
\hline
\end{tabular}

In the experimental group as a whole, and in the men's sample in particular, the level in the "Exper" cale increased and decreased in the "Observer" scale, hat is, students became more independent in forming and expressing their own opinion. In the female part of the control sample for the semester of training has "Apprentice", that is, students are more in need of mentors (curators). Diagnosed alignment of the homogeneity of control and experimental groups at baseline in the beginning of the semester lower level of the formation stage of the learner and higher level the stage of "Expert" in the control group by the end of the seme if corme "Learne" has increased. Also in the control group as a whole and in the male sample the control group as a whole and in the male sample, the decreased. This indicates the contribution to the formation of the stages of subjectivity of students who did not participate in the experiment of other factors of the not paricing the predominance in the contol group of repraductive the predoming the need for mentoring (supervision). A regression an alysis was conducted by us: the experinental group as us. the "Observer" stage in the experimental group as predictors includes the initial value of the "Observer" stage. The "Apprentice" stage already includes two links of relationships: the initial value of this stage before the experiment and the value of the previous "Observer" stage, formed at the end of the experiment. Among the predictors of relationships there are several asymmetric ecopsychological types. Similar conditionality is inherent all stages of the formation of subjectivity as phenomenon of development of consciousness 